American Journal of Environmental Sciences 4 (4): 373-379, 2008

ISSN 1553-345X

(C) 2008 Science Publications

\title{
Metals Concentrations in Tissues of Tilapia gallier, Crarias lazera and Osteoglossidae Caught from Alau Dam, Maiduguri, Borno State, Nigeria
}

\author{
G.A. Dimari, F.I. Abdulrahman, J.C. Akan and S.T. Garba \\ Department of Chemistry, Faculty of Science, University of Maiduguri, \\ P.M.B. 1069, Maidugiri, Borno State, Nigeria
}

\begin{abstract}
An analysis of intestine, liver, stomach and gill tissue concentrations of heavy metals $(\mathrm{Cu}$, $\mathrm{Co}, \mathrm{Pb}, \mathrm{Cr}, \mathrm{Mn}, \mathrm{Fe}, \mathrm{Ni}, \mathrm{Cd}$ and $\mathrm{Zn}$ ) in three commercially important fish species (Tilapia gallier, Crarias lazera and Osteoglossidae. caught within Alau Dam between the periods of January to August, 2007. These heavy metals were determined using Perkin-Elmer AAnalyst 300 Atomic Absorption Spectroscopy (AAS). Heavy metals contents varied significantly $(\mathrm{p}>0.05)$ depending on the fish species and on the types of tissues. The concentration of heavy metals in livers and gills tissue were relatively higher than the intestine and stomach tissues of the three species. The distribution of copper and cobalt were in the order of gills $>$ stomach $>$ liver $>$ intestine in the entire fish samples, while the distribution of $(\mathrm{Pb}, \mathrm{Cr}, \mathrm{Mn}, \mathrm{Fe}, \mathrm{Ni}, \mathrm{Cd}$ and $\mathrm{Zn})$ were in the order of liver>gills>stomach>intestine. The concentrations of the entire elements in the three species were within tolerance limits that are safe for human consumption, with exception of lead in gills.
\end{abstract}

Key words: Metal concentration, Tissues, Tilapia gallier, Crarias lazera and Osteoglossidae, Alau Dam, Borno, Nigeria

\section{INTRODUCTION}

Heavy metals in aquatic environment are a major concern because of their toxicity and threat to plant and animal life disturbing the natural ecological balance. The specific problem associated with the heavy metals in the environment is their accumulation through food chain and persistent in nature. Uptake of heavy metals such as Copper, Nickel, Manganese, Lead, Cadmium, Iron and Cobalt through the food chain in human being may cause various physiological disorders like hypertension, sporadic fever, nausea and renal damage $^{[1]}$. Heavy metal pollution and its management has been a major global concern for environmentalist due to their non-biodegrable and hazardous nature.

With increase agricultural and industrial activities, most of the water sources are becoming contaminated $^{[2]}$. Industrial discharges containing toxic and hazardous substances including heavy metals ${ }^{[3]}$ contribute tremendously to the pollution of aquatic ecosystems. Concentrations of both $\mathrm{Mn}, \mathrm{Fe}, \mathrm{Cr}$ and $\mathrm{Co}$ in gonads, $\mathrm{Cr}$ in bronchial hearts and $\mathrm{Zn}$ in both gills and mantle increased linearly with animal weight ${ }^{[4]}$.

Many of the dissolved metals that enter rivers are adsorbed onto colloid particulates. Also at high alkalinity and $\mathrm{pH}$, the metals, particularly lead and cadmium, precipitate by forming complexation dramatically influence metal toxicity ${ }^{[5,6]}$. Although many heavy metals are considered as essential macro and micro elements especially at non adverse effect levels ${ }^{[7,8]}$, they can exert toxic effects at concentrations encountered in polluted environment. Additionally, metals unlike many organic pollutants are known to biopersist in the environment ${ }^{[9]}$ and can become bioconcentrated in the food chain ${ }^{[10]}$, so that levels in the upper members of the chain are elevated than concentrations in the overlying water column. In recent years, there has been an increasing interest in the utilization of fishes as bioindicators of the integrity of aquatic environmental systems ${ }^{[11-14]}$. Several studies have indicated enhanced levels of both non-essential and essential heavy metal load in muscle and liver tissues of fishes ${ }^{[8,15,16,17]}$.

The frequent presence of $\mathrm{Pb}, \mathrm{Cr}, \mathrm{Zn}$ and $\mathrm{Cd}$ in industrial wastes and its high toxicity along with considerable bioaccumulation in freshwater fishes make them toxicants that should be given due consideration in aquatic toxicology. Fish accumulate xenobiotic chemicals, especially those with poor water solubility and these are the chemicals carries in solution or suspension and also because fish have to extract oxygen from the medium by passing enormous volumes of

Corresponding Author: J.C. Akan, Department of Chemistry, Faculty of Science, University of Maiduguri, P.M.B. 1069, Maiduguri, Borno State, Nigeria, Tel: +2348036000506 
water over the gills. For fish, the gills, skin and digestive tract are potential sites of absorption of water borne chemicals. The chemicals once absorbed are transported by the blood to either a storage point such as bone or to the liver. In the liver, it may be stored, excreted in the bile or passed back into the blood for possible excretion by the kidney or gills or stored in extra hepatic tissues such as fat.

The concentration of heavy metal were found generally higher in the liver and gill than the gonad and muscle tissues in three species Dicentrachus ibrax D. sparus arata D. and Mugli cphalus L.; the levels of all metals in a given tissue were generally higher in Mugil Cephalus ${ }^{[18]}$. The muller fish, Liza Klunzinger, commercially important and widely relished by Kumaiti residents and the stressed ecosystem in Kuwait Bay instigated the investigation of toxicity and bioaccumulation tests on heavy metals $(\mathrm{Pb}, \mathrm{Ni}, \mathrm{V}, \mathrm{Cu}$ and $\mathrm{Fe}$ ). Among five metals $\mathrm{Pb}$ had the lowest observed effect concentration at tissues-gills, kidneys, liver, skin and muscle of Clarias batrachus exposed to sub lethal concentration( $7 \mathrm{ppm}$ ) of cadmium chloride was investigated and the mean rate of accumulation of exposure was in order gills $>$ kidneys $>$ liver $>$ skin $>$ muscle ${ }^{[19]}$.It was Observed that chromium and cadmium in the muscles tissue and gill of six commercially edible fishes is higher than gonads and skin in upper course of gangetic West Bengal, India ${ }^{[20]}$.

Alau Dam is located in Maiduguri, Borno state, Nigeria. The Dam is nine meter high with a square reservoir area of about 50 square kilometer. The maximum storage capacity is 112 million meter cube. Alau Dam received water from River Yedzram and River Gombole which meet at a confluent at Sambisha and flow as River Ngada into Alau Dam. Alau Dam received a wide variety of waste from agricultural land. This waste generated contaminates Alau Dam with a variety of heavy metals acting as point sources. This Lake is also use for commercial fishing.

The present study was carried out to investigate the concentration of heavy metals $(\mathrm{Cu}, \mathrm{Co}, \mathrm{Pb}, \mathrm{Cr}, \mathrm{Mn}, \mathrm{Fe}$, $\mathrm{Ni}, \mathrm{Cd}$ and $\mathrm{Zn}$ ) in three commercially important species of fishes such as Tilapia gallier, Crarias lazera and Osteoglossidae caught within Alou Dam, Maiduguri, Borno state, Nigeria. These species are marketed fresh, smoked and dried.

\section{MATERIALS AND METHODS}

Sample and Sampling: The fish samples (Tilapia gallier, Crarias lazera and Osteoglossidae) were caught using gill nets from Alau Dam. The fishes samples collected were labeled with an identified number. Samples of fishes were taken to the laboratory on the same day and later dissected to remove the intestine, liver, stomach and Gills of each species of fish. Samples were collected six times a month for a period of eight months.

Sample Preparation: The intestines, livers, stomach and gills tissues of each fish samples $(8.0 \mathrm{~g})$ were dried at $105^{\circ} \mathrm{C}$ until they reached a constant weight. Each dried sample was ground, using porcelain mortar and pestle. The ground fish tissues were transferred to porcelain basin and put to a Thermicon $\mathrm{P}$ muffle furnace at a temperature of $550^{\circ} \mathrm{C}$ for $4 \mathrm{hrs}$. Samples were digested with tri-acid mixture $\left(\mathrm{HNO}_{3}: \mathrm{HCLO}_{4}\right.$ $\left.\mathrm{H}_{2} \mathrm{SO}_{4}=10: 4: 1\right)$ at a rate of $5 \mathrm{~mL}$ per $0.5 \mathrm{~g}$ of sample and was placed on hot plate at $100^{\circ} \mathrm{C}$ temperature. Digestion was continued until the liquor was clear ${ }^{[21]}$. All the digested liquors were filtered through Whatmann 541 filter paper and diluted to $25 \mathrm{~mL}$ with distilled water.

Analysis of Heavy Metals: The concentrations of heavy metals in the fish samples were analyzed using Perkin-Elmer AAnalyst 300 Atomic Absorption Spectroscopy (AAS).

\section{RESULTS}

The concentration of heavy metals in intestine samples of Tilapia gallier, Crarias lazera and Osteoglossidae are presented in Table 1. From the result the concentrations of heavy metals ranged from $0.04 \pm 0.06-0.36 \pm 0.01 \mu \mathrm{g} \mathrm{g} \mathrm{g}^{-1} \mathrm{Cu} ; 0.20 \pm 0.01-0.25 \pm 0.02$ $\mu \mathrm{g} \mathrm{g}^{-1} \mathrm{Co} ; 0.12 \pm 0.01-0.31 \pm 0.06 \mu \mathrm{g} \mathrm{g}^{-1} \mathrm{~Pb} ; 0.15 \pm 0.12-$ $0.19 \pm 0.01 \mu \mathrm{g} \mathrm{g}^{-1} \mathrm{Cr} ; 0.14 \pm 0.03-0.32 \pm 0.07 \mu \mathrm{g} \mathrm{g}^{-1} \mathrm{Mn}$; $0.30 \pm 0.02-0.34 \pm 0.04 \mu \mathrm{g} \mathrm{g}^{-1} \mathrm{Fe} ; 0.13 \pm 0.07-0.18 \pm 0.05$ $\mu \mathrm{g} \mathrm{g}^{-1} \mathrm{Ni} ; 0.09 \pm 0.06-0.32 \pm 0.12 \mu \mathrm{g} \mathrm{g}^{-1} \mathrm{Cd} ; 0.15 \pm 0.02-$ $0.43 \pm 0.18 \mu \mathrm{g} \mathrm{g}^{-1} \mathrm{Zn}$.

Levels of heavy metals in Liver samples of the three fish species are presented in Table 2. The concentrations of heavy metals ranged from $0.42 \pm 0.01$ $0.44 \pm 0.03 \mu \mathrm{g} \mathrm{g}^{-1} \mathrm{Cu} ; 0.24 \pm 0.05-0.27 \pm 0.01 \mu \mathrm{g} \mathrm{g}^{-1} \mathrm{Co}$; $0.32 \pm 0.16-0.40 \pm 0.03 \mu \mathrm{g} \mathrm{g}^{-1} \mathrm{~Pb} ; 0.19 \pm 0.12-0.26 \pm 0.04$ $\mu \mathrm{g} \mathrm{g}^{-1} \mathrm{Cr} ; 0.58 \pm 0.08-0.62 \pm 0.02 \mu \mathrm{g} \mathrm{g}^{-1} \mathrm{Mn} ; 0.36 \pm 0.08-$ $0.43 \pm 0.02 \mu \mathrm{g} \mathrm{g}^{-1} \mathrm{Fe} ; 0.57 \pm 0.09-0.62 \pm 0.02 \mu \mathrm{g} \mathrm{g}^{-1} \mathrm{Ni}$ $0.44 \pm 0.11-0.49 \pm 0.04 \mu \mathrm{g} \mathrm{g}^{-1} \mathrm{Cd} ; 0.46 \pm 0.15-0.52 \pm 0.01$ $\mu \mathrm{g} \mathrm{g}{ }^{-1} \mathrm{Zn}$.

Table 3 shows the concentrations of heavy metals in Stomach samples of Tilapia gallier, Crarias lazera and Osteoglossidae. From the result of the study, the 
Am. J. Environ. Sci., 4 (4): 373-379, 2008

Table 1: Concentrations of heavy metals in intestine samples of Tilapia gallier, Crarias and Osteoglossidae caught from Alau Dam, Maiduguri, Borno State, Nigeria

\begin{tabular}{|c|c|c|c|c|c|c|c|c|c|}
\hline \multirow[b]{2}{*}{ Species } & \multicolumn{9}{|c|}{ Concentrations $\left(\mu \mathrm{g} \mathrm{g}^{-1}\right)$} \\
\hline & $\mathrm{Cu}$ & Co & $\mathrm{Pb}$ & $\mathrm{Cr}$ & $\mathrm{Mn}$ & $\mathrm{Fe}$ & $\mathrm{Ni}$ & $\mathrm{Cd}$ & $\mathrm{Zn}$ \\
\hline Tilapia gallier & $0.36^{\mathrm{a}} \pm 0.01$ & $0.25^{\mathrm{a}} \pm 0.02$ & $0.12^{\mathrm{a}} \pm 0.01$ & $0.18^{\mathrm{a}} \pm 0.03$ & $0.14^{\mathrm{a}} \pm 0.03$ & $0.34^{\mathrm{a}} \pm 0.04$ & $0.13^{\mathrm{a}} \pm 0.07$ & $0.09^{\mathrm{a}} \pm 0.06$ & \pm 0.02 \\
\hline Crarias & $0.36^{\mathrm{a}} \pm 0.03$ & $0.20^{\mathrm{b}} \pm 0.01$ & $0.13^{\mathrm{a}} \pm 0.02$ & $0.19^{\mathrm{a}} \pm 0.01$ & $0.15^{\mathrm{a}} \pm 0.02$ & $0.32^{\mathrm{b}} \pm 0.07$ & $0.14^{\mathrm{a}} \pm 0.10$ & $0.10^{\mathrm{a}} \pm 0.05$ & $0.17^{\mathrm{b}} \pm 0.03$ \\
\hline Osteoglossidae & $0.04^{\mathrm{b}} \pm 0.06$ & $0.22^{\mathrm{c}} \pm 0.08$ & $0.31^{\mathrm{b}} \pm 0.16$ & $0.15^{\mathrm{b}} \pm 0.12$ & $0.32^{\mathrm{b}} \pm 0.07$ & $0.30^{\mathrm{c}} \pm 0.02$ & $0.18^{\mathrm{b}} \pm 0.05$ & $0.32^{\mathrm{b}} \pm 0.12$ & $0.43^{\mathrm{c}} \pm 0.18$ \\
\hline
\end{tabular}

Note: The values given in the table above are means of replicate values $(n=48)$ and within columns, means with different letters are statistically significant, $(\mathrm{P}<0.05)$

Table 2: Concentrations of heavy metals in liver samples of Tilapia gallier, Crarias and Osteoglossidae caught from Alau Dam, Maiduguri, Borno State, Nigeria

\begin{tabular}{|c|c|c|c|c|c|c|c|c|c|}
\hline \multirow[b]{2}{*}{ Species } & \multicolumn{9}{|c|}{ Concentrations $\left(\mu \mathrm{g} \mathrm{g}^{-1}\right)$} \\
\hline & $\mathrm{Cu}$ & Co & $\mathrm{Pb}$ & $\mathrm{Cr}$ & $\mathrm{Mn}$ & $\mathrm{Fe}$ & $\mathrm{Ni}$ & $\mathrm{Cd}$ & $\mathrm{Zn}$ \\
\hline Tilapia gallier & $0.44^{\mathrm{b}} \pm 0.03$ & $0.27^{\mathrm{a}} \pm 0.01$ & $0.40^{\mathrm{a}} \pm 0.03$ & $0.26^{\mathrm{a}} \pm 0.04$ & $0.35^{\mathrm{a}} \pm 0.02$ & $0.40^{\mathrm{a}} \pm 0.03$ & $0.62^{\mathrm{a}} \pm 0.02$ & $0.49^{\mathrm{a}} \pm 0.04$ & $0.52^{\mathrm{a}} \pm 0.01$ \\
\hline Crarias & $0.42^{\mathrm{b}} \pm 0.01$ & $0.25^{\mathrm{b}} \pm 0.04$ & $0.38^{\mathrm{b}} \pm 0.03$ & $0.25^{\mathrm{a}} \pm 0.03$ & $0.30^{\mathrm{b}} \pm 0.09$ & $0.43^{\mathrm{b}} \pm 0.02$ & $0.57^{\mathrm{b}} \pm 0.09$ & $0.44^{\mathrm{b}} \pm 0.11$ & $0.48^{\mathrm{b}} \pm 0.08$ \\
\hline Osteoglossidae & $0.42^{\mathrm{b}} \pm 0.03$ & $0.24^{\mathrm{b}} \pm 0.05$ & $0.32^{\mathrm{c}} \pm 0.16$ & $0.19^{\mathrm{b}} \pm 0.12$ & $0.32^{\mathrm{c}} \pm 0.07$ & $0.36^{\mathrm{c}} \pm 0.08$ & $0.59^{c} \pm 0.05$ & $0.47^{\mathcal{c}} \pm 0.05$ & $0.46^{c} \pm 0.15$ \\
\hline
\end{tabular}

Note: The values given in the table above are means of replicate values $(\mathrm{n}=48)$ and within columns, means with different letters are statistically significant, $(\mathrm{P}<0.05)$

Table 3: Concentrations of heavy metals in stomach samples of Tilapia gallier, Crarias and Osteoglossidae caught from Alau Dam, Maiduguri, Borno State, Nigeria

Concentrations $\left(\mu \mathrm{g} \mathrm{g}^{-1}\right)$

\begin{tabular}{llllllllll} 
Species & $\mathrm{Cu}$ & $\mathrm{Co}$ & $\mathrm{Pb}$ & $\mathrm{Cr}$ & $\mathrm{Mn}$ & $\mathrm{Fe}$ & $\mathrm{Ni}$ & $\mathrm{Cd}$ & $\mathrm{Zn}$ \\
\hline Tilapia gallier & $0.52^{\mathrm{a}} \pm 0.02$ & $0.44^{\mathrm{a}} \pm 0.01$ & $0.40^{\mathrm{a}} \pm 0.02$ & $0.20^{\mathrm{a}} \pm 0.02$ & $0.30^{\mathrm{a}} \pm 0.01$ & $0.30^{\mathrm{a}} \pm 0.03$ & $0.16^{\mathrm{a}} \pm 0.04$ & $0.22^{\mathrm{a}} \pm 0.02$ & $0.18^{\mathrm{a}} \pm 0.02$ \\
Crarias & $0.49^{\mathrm{b}} \pm 0.06$ & $0.41^{\mathrm{b}} \pm 0.05$ & $0.38^{\mathrm{b}} \pm 0.05$ & $0.23^{\mathrm{b}} \pm 0.01$ & $0.31^{\mathrm{a}} \pm 0.03$ & $0.29^{\mathrm{a}} \pm 0.04$ & $0.15^{\mathrm{a}} \pm 0.02$ & $0.19^{\mathrm{b}} \pm 0.06$ & $0.22^{\mathrm{b}} \pm 0.10$ \\
Osteoglossidae & $0.41^{\mathrm{c}} \pm 0.20$ & $0.40^{\mathrm{c}} \pm 0.03$ & $0.35^{\mathrm{c}} \pm 0.20$ & $0.20^{\mathrm{a}} \pm 0.02$ & $0.34^{\mathrm{b}} \pm 0.01$ & $0.33^{\mathrm{b}} \pm 0.03$ & $0.19^{\mathrm{b}} \pm 0.05$ & $0.28^{\mathrm{c}} \pm 0.08$ & $0.16^{\mathrm{c}} \pm 0.04$ \\
\hline
\end{tabular}

Table 4: Concentrations of heavy metals in gills samples of Tilapia gallier, Crarias and Osteoglossidae caught from Alau Dam, Maiduguri, Borno State, Nigeria

\begin{tabular}{|c|c|c|c|c|c|c|c|c|c|}
\hline \multirow[b]{2}{*}{ Species } & \multicolumn{9}{|c|}{ Concentrations $\left(\mu \mathrm{g} \mathrm{g}^{-1}\right)$} \\
\hline & $\mathrm{Cu}$ & Co & $\mathrm{Pb}$ & $\mathrm{Cr}$ & $\mathrm{Mn}$ & $\mathrm{Fe}$ & $\mathrm{Ni}$ & $\mathrm{Cd}$ & $\mathrm{Zn}$ \\
\hline Tilapia gallier & $0.63^{\mathrm{a}} \pm 0.03$ & $0.54^{\mathrm{a}} \pm 0.02$ & $0.53^{\mathrm{a}} \pm 0.04$ & $0.42^{\mathrm{a}} \pm 0.02$ & $0.62^{\mathrm{a}} \pm 0.02$ & $0.33^{\mathrm{a}} \pm 0.01$ & $0.47^{\mathrm{a}} \pm 0.01$ & $0.38^{\mathrm{a}} \pm 0.02$ & $0.36^{\mathrm{a}} \pm 0.02$ \\
\hline Crarias & $0.58^{\mathrm{b}} \pm 0.12$ & $0.52^{\mathrm{b}} \pm 0.01$ & $0.48^{\mathrm{b}} \pm 0.11$ & $0.44^{\mathrm{b}} \pm 0.01$ & $0.58^{\mathrm{b}} \pm 0.08$ & $0.33^{\mathrm{a}} \pm 0.01$ & $0.44^{\mathrm{b}} \pm 0.07$ & $0.36^{\mathrm{b}} \pm 0.04$ & $0.38^{\mathrm{b}} \pm 0.03$ \\
\hline Osteoglossidae & $0.61 c \pm 0.06$ & $0.54^{\mathrm{a}} \pm 0.02$ & $0.51^{\mathrm{c}} \pm 0.05$ & $0.49^{c} \pm 0.14$ & $0.62^{\mathrm{a}} \pm 0.02$ & $0.39^{\mathrm{b}} \pm 0.16$ & $0.38^{\mathrm{c}} \pm 0.17$ & $0.35^{\mathrm{c}} \pm 0.12$ & $0.39^{\mathrm{b}} \pm 0.05$ \\
\hline
\end{tabular}

Note: The values given in the table above are means of replicate values $(\mathrm{n}=48)$ and within columns, means with different letters are statistically significant, $(\mathrm{P}<0.05)$

concentrations of heavy metals ranged from $0.41 \pm 0.20$ $0.52 \pm 0.02 \mu \mathrm{g} \mathrm{g}^{-1} \mathrm{Cu} ; 0.40 \pm 0.03-0.44 \pm 0.01 \mu \mathrm{g} \mathrm{g}{ }^{-1} \mathrm{Co}$ $0.35 \pm 0.20-0.40 \pm 0.02 \mu \mathrm{g} \mathrm{g}^{-1} \mathrm{~Pb} ; 0.20 \pm 0.02-0.23 \pm 0.01$ $\mu \mathrm{g} \mathrm{g}^{-1} \mathrm{Cr} ; 0.30 \pm 0.03-0.34 \pm 0.01 \mu \mathrm{g} \mathrm{g}^{-1} \mathrm{Mn} ; 0.29 \pm 0.04-$ $0.33 \pm 0.03 \mu \mathrm{g} \mathrm{g}^{-1} \mathrm{Fe} ; 0.15 \pm 0.02-0.19 \pm 0.05 \mu \mathrm{g} \mathrm{g}{ }^{-1} \mathrm{Ni}$ $0.19 \pm 0.06-0.28 \pm 0.08 \mu \mathrm{g} \mathrm{g}^{-1} \mathrm{Cd} ; 0.16 \pm 0.04-0.22 \pm 0.10$ $\mu \mathrm{g} \mathrm{g}^{-1} \mathrm{Zn}$.

The concentrations of heavy metals in Gills samples of Tilapia gallier, Crarias lazera and Osteoglossidae are presented in Table 4. The concentrations of heavy metals ranged from $0.58 \pm 0.12$ $0.63 \pm 0.03 \mu \mathrm{g} \mathrm{g}^{-1} \mathrm{Cu} ; 0.52 \pm 0.01-0.54 \pm 0.02 \mu \mathrm{g} \mathrm{g}^{-1} \mathrm{Co}$; $0.48 \pm 0.11-0.53 \pm 0.04 \mu \mathrm{g} \mathrm{g}^{-1} \mathrm{~Pb} ; 0.42 \pm 0.02-0.49 \pm 0.14$ $\mu \mathrm{g} \mathrm{g}^{-1} \mathrm{Cr} ; 0.30 \pm 0.09-0.35 \pm 0.02 \mu \mathrm{g} \mathrm{g}^{-1} \mathrm{Mn} ; 0.33 \pm 0.01$ -
$0.39 \pm 0.16 \mu \mathrm{g} \mathrm{g}^{-1} \mathrm{Fe} ; 0.38 \pm 0.17-0.47 \pm 0.01 \mu \mathrm{g} \mathrm{g}^{-1} \mathrm{Ni}$; $0.35 \pm 0.12-0.38 \pm 0.02 \mu \mathrm{g} \mathrm{g}^{-1} \mathrm{Cd} ; 0.36 \pm 0.02-0.39 \pm 0.05$ $\mu \mathrm{g} \mathrm{g}^{-1} \mathrm{Zn}$.

\section{DISCUSSION}

Copper accumulated in Gills, intestine, liver and stomach tissues of Tilapia gallier, Crarias lazera and Osteoglossidae. The distribution of copper were in the order of gills $>$ stomach $>$ liver $>$ intestine in the entire fish samples. Gills concentrate higher levels of copper while the lowest detected concentrations were found in the intestine. This high levels of copper, is due to the fact that freshwater fishes gills might be expected to be the 
primary route for the uptake of waterborne pollutants ${ }^{[22]}$. Copper toxicity in fish is taken up directly from the water via gills, the present study showed the similar accumulation of copper in the gills ${ }^{[23]}$. Effects of high concentrations of copper on fish are not well established; however, there is evidence that high concentrations in fish can experience toxicity ${ }^{[24]}$ Copper can combine with other contaminants such as ammonia, mercury and zinc to produce an additive toxic effect on fish $^{[25,26]}$. However, the concentrations of copper levels in gills, intestine, liver and stomach tissues of Tilapia gallier, Crarias lazera and Osteoglossidae from AlauDam were below the maximum level of $1.0 \mu \mathrm{g} \mathrm{g}^{-1}$ reported by ${ }^{[27]}$.

The maximum concentrations of cobalt were detected in the gills of all species collected from Alau Dam. Cobalt has not been considered in compliance policies or MCL and NCBP guideline. In Tilapia gallier, Crarias lazera and Osteoglossidae livers were the target organs of cobalt (Table 4), while intestine showed the lowest concentration (Table 1). The concentrations of Cobalt in the livers range from $0.52 \pm 0.01-0.54 \pm 0.02 \mu \mathrm{g} \mathrm{g}^{-1}$ and in intestine $0.20 \pm 0.01-$ $0.25 \pm 0.02 \mu \mathrm{g} \mathrm{g}^{-1}$. The result is in line with the work of ${ }^{[28]}$ which indicate that in fish, the liver is the major storage organs for cobalt. Accumulation in the liver can be the result of detoxicating mechanisms and may originate from metal in the food. However, the liver is the preferred organs for metals accumulation as could be deduced from the present study ${ }^{[29,30]}$.

Lead accumulates significantly in gills, livers, stomach and intestine tissue of Tilapia gallier, Crarias lazera and Osteoglossidae. The concentrations of lead were higher in the following order gills $>$ liver $>$ stomach $>$ intestine. Similar findings were reported by ${ }^{[31]}$ that highest concentrations were in gills, kidney and spleen in rainbow trout. ${ }^{[32]}$ Noticed in O. niloticus, the gill consistently accumulated higher amount of lead as lead nitrate. Lead is highly toxics to aquatic organisms, especially fish ${ }^{[26]}$.

The biological effects of sublethel concentrations of lead include delayed embryonic development, suppressed reproduction and inhalation of growth, increased mucous formation, neurological problems, enzyme inhalation and kidney disfunction ${ }^{[26,33]}$. Lead concentrations in the gills of Tilapia gallier, Crarias lazera and Osteoglossidae exceeded the $0.5 \mu \mathrm{g} \mathrm{g}^{-1}$ dry weight having the potential to harm fish reproduction and surviva ${ }^{[34]}$. While levels of lead in livers, stomach and intestine tissue of Tilapia gallier, Crarias lazera and Osteoglossidae were below the $0.5 \mu \mathrm{g} \mathrm{g}^{-1}$ limits $^{[34]}$. The concentration of chromium in the gills tissues are varied from $0.42 \pm 0.02-0.49 \pm 0.14 \mu \mathrm{g} \mathrm{g}^{-1}$ in the three species of fish to $0.15 \pm 0.12-0.19 \pm 0.01 \mu \mathrm{g} \mathrm{g}^{-1}$ in the intestine. It was found that the concentrations of chromium in the different organs of three fish species caught from Alau Dam varied from one organ to another. Their lowest detection concentrations were found in the intestine tissues (Table 1). On the other hand, the highest concentrations of $\mathrm{Cr}$ were found in gills (Table 4). Chromium is an essential trace element in human and some laboratory animals ${ }^{[35]}$, but in excess, it could have lethal and sublethal effects on fish and wildlife ${ }^{[36]}$. No guideline documents are available for Chromium in the edible part of fish; neither was it assessed by NCBP or FEPA.

In view of other sanctions, the present Chromium concentrations $0.42 \pm 0.02-0.49 \pm 0.14 \mu \mathrm{g} \mathrm{g}^{-1}$ in gills which was the highest are well below the levels validated by USEPA $(53.8 \mathrm{ppm})$ for fish tissue ${ }^{[37]}$. However, surveys of contaminants in edible shellfish conducted by FDA $^{[38]}$ and National Marine Fisheries Service reported chromium levels from 0.1 up to $0.9 \mu \mathrm{g}$ $\mathrm{g}^{-1}$ [39], which is in line with the above threshold. The present chromium tissues concentrations (Table 1-4) are also below $4.0 \mu \mathrm{g} \mathrm{g}^{-1}$ levels suggested by ${ }^{[40]}$ as indicative of $\mathrm{Cr}$ contamination.

Manganese (Mn) occurs naturally in sediments; in Tilapia gallier, Crarias lazera and Osteoglossidae, it seems that $\mathrm{Mn}$ tend to reside in the liver (Table 2), while intestine is the least accumulated organ. Hence, Mn concentrations in the entire species of fish were below quide line limit of $0.7 \mu \mathrm{g} \mathrm{g}^{-1}$ set by ${ }^{[41]}$ and do not constitute any treat upon the consumption of these species of fish.

Earlier reports showed Fe to be normally highest in gills $^{[42]}$ or in the liver ${ }^{[41]}$, in contrast the present study showed liver with the highest $\mathrm{Fe}$ concentrations (Table 2). The highest concentrations of $0.36 \pm 0.08$ $0.43 \pm 0.02 \mu \mathrm{g} \mathrm{g}^{-1}$ for Fe (Table 2) were below the high residue concentrations of $\mathrm{Fe}$ (34-107 ppm) in fish samples on MNW Refuge ${ }^{[41]}$.

The maximum concentrations of Nickel were detected in the livers of all species collected from AlauDam. From the result of these study, the concentrations of nickel are in the order liver $>$ gill $>$ stomach $>$ intestine. The highest concentrations of $\mathrm{Ni}$ observed in liver tissues of Tilapia gallier, Crarias lazera and Osteoglossidae ranged from $0.57 \pm 0.09-0.62 \pm 0.02 \mu \mathrm{g}$ $\mathrm{g}^{-1}$ (Table 2). 
Nickel level of $0.7 \mu \mathrm{g} \mathrm{g}^{-1}$ is considered potentially lethal to fish and aquatic birds that consume them ${ }^{[43]}$. Nickel concentrations of $2.3 \mu \mathrm{g} \mathrm{g}^{-1}$ or greater, may cause reproductive impairment and lack of recruitment in fishes ${ }^{[44]}$. None of the samples in this study approached these levels of concern. Hence, nickel concentrations in the entire species of fish do not constitute any treat upon the consumption of these species of fish.

Cadmium is a nonessential trace metal that is potentially toxic to most fish and wildlife, particularly freshwater organisms ${ }^{[36]}$. The highest concentrations of Cd $\left(0.44 \pm 0.11-0.49 \pm 0.04 \mu \mathrm{g} \mathrm{g}^{-1}\right)$ were observed in liver tissues of Tilapia gallier, Crarias lazera and Osteoglossidae, while the lowest concentrations of $\left(0.09 \pm 0.06-0.32 \pm 0.12 \mu \mathrm{g} \quad \mathrm{g}^{-1}\right)$ were detected in intestine. These values detected exceeded the NCBP concentration of $0.05 \mu \mathrm{g} \mathrm{g}^{-1}{ }^{[27]}$. The highest concentration of $\left(0.44 \pm 0.11-0.49 \pm 0.04 \mu \mathrm{g} \mathrm{g}^{-1}\right)$ in liver tissues approached the $0.5 \mu \mathrm{g} \mathrm{g}^{-1}$ threshold considered harmful to fish and predators ${ }^{[34}$.

Zinc (Zn): Zinc was detected in all the fish samples and the highest concentrations were observed in liver tissues followed by Gills and stomach, while intestine shows the least concentrations. The concentrations of $\mathrm{Zn}$ in Tilapia gallier, Crarias lazera and Osteoglossidae were below the NCBP $34.2 \mu \mathrm{g} \mathrm{g}^{-1}$. Fish can accumulate zinc from both the surrounding water and from their diet ${ }^{[45]}$. Although zinc is an essential element, at high concentrations, it can be toxic to fish, cause mortality, growth retardation and reproductive impairment ${ }^{[46]}$. Zinc is capable of interacting with other elements and producing antagonistic, additive or synergistic effects ${ }^{[44]}$. Zinc does not appear to present a contaminant hazard to fish within this portion of Alau Dam.

Results of analysis of variance (ANOVA) indicate that variations among species were statistically significant for all the metals with exception of some metals ( $p>0.05$ ). In general, this study revealed that the livers and gills tissues of Tilapia gallier, Crarias lazera and Osteoglossidae, indicating higher preference for the bioaccumulation of metals than the stomach and intestine.

\section{CONCLUSION}

Since there are many environmental factors which have been claimed by various researchers to influence the bioaccumulation of heavy metals to toxics levels in organisms, it would be unreasonable to attribute the levels of these metals in Tilapia gallier, Crarias lazera and Osteoglossidae to any specific factors. It is perhaps more rational to posit that these elemental tissue load might have been largely influenced by their feeding habits as well as the contamination gradients of the Alau Dam.

From the results of this study, the concentration of heavy metals in the livers, gills, intestine and stomach tissues of the three species investigated did not exceed the acceptable levels proposed for human consumption (USEPA, 1995) with exception of lead in gills. However, the levels of metals in the species call for serious concern as they could bioaccumulate and biopersist in these tissues over time.

\section{ACKNOWLEDGEMENT}

I would like to acknowledge Mr Fine Akawo for his laboratory assistance.

\section{REFERENCES}

1. NRC (National Research Council), 1999-2000. Dogfish liver (Dolt-2), Dogfish Muscle (Dolt-2), Non Defatted lobster Hepatopancreas (LUTS-1) and Marine Lobsters Hepatopancreas (Tort-2) Reference materials for Trace Metals. In: Chemical Metrology, introduction to NRC Certified Reference Materials (CRMS)- Institude for National Measurement standard (INMS). Catalogue Number and Date sheet: DOLT-2 INMS CRMs. Institute for Marine Biosciences, Halifax, Government of Canada.

2. Khare, S. and S. Singh, 2002. Histopathological lesions by copper sulphate and lead nitrate in the gills of fresh water fish Nandus. J. Ecotoxicol. Environ. Monit., 12: 105-11.

3. Gbem, T.T., J.K. Balogun, F.A. Lawaland and P.A. Annune, 2001. Trace metals accumulation in Clarias gariepinus Teugules exposed to sun lethal levels of tannery effluent. Sci. Total Environ., 271: 1-9.

4. Nessim Ramzy, B. and R. Rafik, 2003. Bioaccumulation of heavy metals in Octopus Vulgaris from Coastal waters of Alexandria (Eastern Mediterranean). Chem. Ecol., 19: 275-81.

5. Van Aardt, W.J. and J. Booysen, 2004. Water hardness the effects of $\mathrm{Cd}$ on oxygen consumption, plasma chlorides and bioaccumulation in Tilapa sparrmanil. Water SA., 30: 57-64. 
6. Van Aardt, W.J. and L.C.R. Venter, 2004. The effects of lead, water hardness and $\mathrm{pH}$ on oxygen consumption, plasma chlorides and bioaccumulation in Tilapia sparrmanil. Arf. J. Aqua. Sci., 29: 37-46.

7. Borovick, A.S., 1990. Characteristic of metals ions in Biological systems. In: Heavy metals tolerance in plants: Shaw, A.J. (Ed). Evolutionary aspects. CRC press Inc., Florida.

8. Hossain, M.S. and Y.S.A. Khan, 2001. Trace metals in penaeid shrimp and spiny lobster from the Bay of Bengal. Sci. Asia., 27: 165-68.

9. Radojevic, M. and V.N. Bashkin, 1999. Practical Environmental Analysis. The Royal Society of Chemistry, Cambridge, pp: 371-74.

10. Eja, M.E., O.R. Ogri and Arikpo, 2003. Bioconcentration of heavy metals in surface sediments from the Great Kwa river estuary, Calabar, Southeastern. Nig. J. Environ. Soc., 1: 247-56.

11. Fausch, K.D., J. Lyons, J.R. Karr and P.L. Angermeier, 1990. Fish communities as indicators of environmental degradation. Am. Fish. Symposium., 8: 123-44.

12. Whitefield, A.K., 1996. Fishes and the environmental status of South African estuaries. Fish. Manag. Ecol., 3: 45-57.

13. Widianarko, B., C.A.M. Vangestel, R.A. Vreweij and N.M. Vanstraalen, 2000. Associations between trace metals in sediment, water and guppy, poecilia reticulate (peters), from urban streams of semerang, Idonesia. Ecotoxicol. Environ. Saf., 45: 15-35.

14. Akueshi, E.U., E. Oriegie, N. Ocheakiti and S. Okunsebor, 2003. Levels of some heavy metals in fish from mining lake on the Jos Plateau, Nigeria. Afr. J. Nat. Sci., 6: 82-86.

15. Ekpo, B.O. and U.J. Ibok., 1999. Temporary variation and distribution of trace metals in fresh water and fish from Calabar River S.E., Nigeria. Environ. Geochem. Health, 21: 51-66.

16. Zyadah, M.A., 1999. Accumulation of some heavy metals in Tilapia zilli organs from lake Manzalah, Egypt. Turk. J. Zool., 23: 365-72.

17. Flessas, C., Y. Coulillard, B. Pinel-Alloul, L. St-Cur and P.G.C. Campbell, 2000. Metals concentrations in two freshwater gastropods (Mollusca) in the St. Lawrence River and relationship with environmental contamination. Can. J. Fish. Aquatic. Sci., 57: 126-37.
18. Dural Meltem, M.Z., L. Goksu, A.A. Ozak and B. Derici, 2005. Bioaccumulation of some heavy metals in different tissues of Cicentrarchus labrax L., 1758, Sparus aurata L., 158 and Mugli cephalus L., 1758 from the Camlik Lagoon of the Eastern Coast of Mediterranean (Turkey). Water Air Soil Pollut., 175: 1573-2932.

19. Jayakumar, P. and V.I. Paul, 2006. Patterns of cadmium accumulation in selected tissues of the catfish Clarias batrachus (Linn) exposed to sub lethal concentration of cadmium chloride. Vet. Arhiv., 76: 167-77.

20. Bhattacharya, A.K., S.N. Mandal and S.K. Das, 2006. Bioaccumulation of chromium and cadmium in commercial edible fishes of gangetic west Bengal. Trends. Applied. Sci. Res., 1: 511-17.

21. AOAC, 1990. Official methods of analysis of the Association of Official Analytical Chemists. 14th edn. Arlington, VA: The Association of Official Analytical Chemists, Inc., pp: 444-53.

22. Allen, G.T. and R.M. Wilson, 1991. Metals and organic compounds in fish of the Missouri River: Boyd County, Nebraska to Kansas City, Missouri. US FWS, Manhattan, Kansas.

23. WHO, 1989. Environmental health criteria 108: Nickel. International programme on chemical safety. World Health Organization. http:॥www.inchem.org/documents/ehc

24. Woodward, D.F., W.G. Brumbaugh, A.J. Deloney, E.E. Little and C.E. Smith, 1994. Effect of contaminant metals on fish in the Clark Fork River in Montana. Trans. Am. Fish. Soc., 123: 51-62.

25. Herbert, D.M. and J.M. Vandyke, 1964. The toxicity to fish of mixtures of poisons. Ann. Appl. Biol., 53: 415-21.

26. Rompala, J.M., F.W. Rutosky and D.J. Putnam, 1984. Concentrations of environmental contaminants from selected waters in Pennsylvania. U.S. Fish Wildl. Serv. Rep., State College, Pennsylvania., pp: 102.

27. Schmitt, C.J. and W.G. Brumbaugh, 1990. National contaminant biomonitoring program:concentrations of arsenic, cadmium, copper, lead, mercury, selenium and zinc in U.S. freshwater fish, 19761984. Arch. Environ. Contam. and Toxicol., 19: 731-47. 
28. Buckley, J.T., M. Roch, C.A. Rendell and M.T. Matheson, 1982. Chronic exposure of coho salmon to sublethel concentration of copper, effect on growth, accumulation and distribution of copper and on copper tolerance. Comp. Biochem. Physiol., 72 (c): 15-19.

29. Karadede, H. and E. Unlu, 1998. Investigations of the heavy metal accumulations in Cyprinion macrostomnus (Heckel, 1843) (Cyprindae) from the Atatuk Dam Lake. XIV Turkish Biol. cong., 7: $165-68$.

30. Shoham-Frider, E., A. Amiel, M. Roditi-Elasar and N. Kress, 2002. Risso dolphin (Grampus griseus) stranding on the coast of Isreal (easter Meditranean). Autopsy results and trace metals concentrations. Sci. Total Environ., 295: 157-66.

31. Buhler, D.R., R.M. Stokes and S.R. Coldwell, 1977. Tissue accumulation and enzymatic effects of hexavalent chromium in Rainbow Trout (Salmo gairdneri). J. Fish Res. Board Can., 34: 9-18.

32. Oladimeji, A.A. and B.O. Offem, 1989. Toxicityof lead to Clarias lazera, Oreochromis niloticus, Chironomus tantans and Benacus sp. Water Air soil Pollu., 44: 191-201.

33. Leland, H.V. and J.S. Kuwabara, 1985. Trace Metals. In Rand G.M. and S.R. Petrocelli, edn. Fundamentals of Aquatic Toxicology. Hemisphere Publ. Co., New York, pp: 374-415.

34. Walsh, D.F., B.L. Berger and J.R. Bean, 1977. Mercury, arsenic, lead, cadmium and selenium residues in fish. 1971-1973. National Pesticide Monitoring Program. Pestic. Monit. J., 11: 5-134.

35. Lee, M.C. and T.W. Schultz, 1994. Contaminants investigation of the Guadalupe and San Antonio rivers of Texas, 1992, U.S. Fish Wild. Serv, Region 2, Contaminants Program, July 1994, Wildlife Enhancement, Corpus Christi Field Office, Campus Box 338, 6300 Ocean Drive, Corpus Christi, Texas 78412.

36. Robertson, S.M., L.R. Gamble and T.C. Maurer, 1991. Contaminant survey of La Sal Vieja, Willacy County, Texas, 1989. U.S. Fish Wild. Serv., Region 2, Contaminants Program. Fish and Wildlife Enhancement, Corpus Christi Field Office, Campus Box 338, 6300 Ocean Drive, Corpus Christi, Texas 78412, Study Identifier 89-2-100.
37. Pastorok, P., 1987. Guidance manual for assessing human health risks from chemically contaminated fish and shellfish. PTI Environmental Service's submission to Battelle New England for EPA, Washington, DEC. PTI Environ. Draft Report C737-01. Bellevue, Washington, pp: 91.

38. FDA (US Food and Drug Administration), 1998. Environmental chemical contaminants and pesticides, hazard analysis worksheet, A chemical hazard, Center for Food Safety and Applied Nutrition, fish and fishery products hazards and controls guide, chapter 9, 1998.

39. Adams, M.A., M. Bolger, C.D. Carrington, C.E. Coker, G.M. Cramer, M.J. DiNovi and S. Dolan, 1993. Guidance document for chromium in shellfish, center for food safety and applied nutrition, US FDA, 200 C St., S.W., Washington, D.C., 20204.

40. Eisler, R., 1986. Chromium hazards to fish, wildlife and invertebrates: a synoptic review. U.S. Fish Wild. Serv. Biol. Rep., 85 (1.6): 60.

41. Charbonneau, C.S. and T. Nash, 1993. Contaminants program, Mingo National Wildlife Refuge (Region 3), contaminants survey results. U.S. Fish and Wildlife Service, 608 East Cherry Street, Room 200, Columbia, Missouri 65201.

42. Philips. D.J.H., 1976. The common mussel Mytillus edulis as an indicator of pollution by $\mathrm{Zn}$, $\mathrm{Cd}, \mathrm{Pb}$ and $\mathrm{Cu}$. 1. Effect of environmental variables on uptake of metals. Mar. Biol., 38: 59-66.

43. Lemly, A.D., 1993. Guidelines for evaluating selenium data from aquatic monitoring and assessment studies. Environ. Monit. and Assess., 28: 83-100.

44. Baumann, P.C. and T.W. May, 1984. Nickel residues in fish from inland waters of the United States. In Workshop proceedings, the effects of trace elements on aquatic ecosystems. Electric Power Research Institute, Palo Alto, CA, 7: 1-16.

45. Eisler, R., 1993. Zinc hazards to fish, wildlife and invertebrates: a synoptic review. U.S. Fish Wildl. Serv. Biol. Rep., 85 (1.10): 90.

46. Sorenson, E.M., 1991. Metal Poisoning in Fish. CRC Press, Inc. Boca Raton, Florida, pp: 119-174. 